\title{
Invited review: Microfiltration-derived casein and whey proteins from milk
}

\author{
B. G. Carter, ${ }^{1}$ N. Cheng, ${ }^{1}$ R. Kapoor, ${ }^{2}$ G. H. Meletharayil, ${ }^{2} \odot$ and M. A. Drake ${ }^{1 *} \oplus$ \\ ${ }^{1}$ Department of Food, Bioprocessing and Nutrition Sciences, Southeast Dairy Foods Research Center, North Carolina State University, \\ Raleigh 27695 \\ ${ }^{2}$ National Dairy Council, Rosemont, IL 60018
}

\begin{abstract}
Milk, a rich source of nutrients, can be fractionated into a wide range of components for use in foods and beverages. With advancements in filtration technologies, micellar caseins and milk-derived whey proteins are now produced from skim milk using microfiltration. Microfiltered ingredients offer unique functional and nutritional benefits that can be exploited in new product development. Microfiltration offers promise in cheesemaking, where microfiltered milk can be used for protein standardization to improve the yield and consistency of cheese and help with operation throughputs. Micellar casein concentrates and milk whey proteins could offer unique functional and flavor properties in various food applications. Consumer desires for safe, nutritious, and clean-label foods could be potential growth opportunities for these new ingredients. The application of micellar casein concentrates in protein standardization could offer a window of opportunity to US cheese makers by improving yields and throughputs in manufacturing plants.
\end{abstract}

Key words: milk protein, whey protein, casein, micellar casein

\section{INTRODUCTION}

Concurrent with the global increase in per capita income, demand is increasing for proteins, including dairy proteins. Dairy proteins are generally superior in nutritional quality compared to most plant-based proteins (Hoffman and Falvo, 2004; Rutherfurd et al., 2015). Some of the common dairy protein applications include infant formula, canned milk, dairy products, and baked goods. Dairy proteins are also sought after for their functional properties, and ingredients are now widely used as clean-label solutions. Dairy proteins fractionated from filtration processes are among the top clean-label alternatives.

Received April 29, 2020.

Accepted October 5, 2020.

*Corresponding author: maryanne_drake@ncsu.edu
Milk is an important source of macronutrients, such as fat, proteins, sugar (in the form of lactose), and 10 other important micronutrients, including minerals (Haug et al., 2007). Two of the next-generation dairy protein ingredients that can be isolated from milk are micellar casein and milk-derived whey protein, which are isolated from skim milk using microfiltration (MF). These ingredients are gaining considerable attention from food and beverage manufacturers because of their unique protein profile and functionality. The purpose of this review is to summarize the current state of the science with respect to these ingredients. This review will also highlight the unique characteristics of these protein ingredients and outline opportunities for their use in food and beverage applications.

\section{Membrane Processing to Separate Milk Components}

The 1960s marked the beginning of modern membrane technology when Loeb and Sourirajan invented a reverse osmosis (RO) membrane for water desalination at the University of California in Los Angeles (Loeb and Sourirajan, 1963). The dairy industry adopted membrane technology in the 1970s and continues to add value to dairy components and ingredients by further advancing its adaptation.

Four major pressure-driven membrane processes are used in dairy. Based on pore size and molecular-weight cutoff, the separation process can be classified as MF, UF, nanofiltration, and RO (Figure 1). Microfiltration has the largest pore size $(0.1-10 \mu \mathrm{m})$ and the lowest processing pressure $(0.01-0.2 \mathrm{MPa})$ and was originally introduced in the dairy industry as a pretreatment to reduce microbial load (Pouliot, 2008). Because MF covers a wide pore size range, it can separate different macromolecules depending on particle size. When a 1.4 $\mu \mathrm{m}$ MF membrane is used, both bacteria $(10-100 \mu \mathrm{m})$ and large milk fat globules $(10 \mu \mathrm{m})$ are rejected by the membrane (called retentate), and micellar casein $(50-500 \mathrm{~nm})$ and whey proteins $(3-6 \mathrm{~nm})$, lactose (1 $\mathrm{nm})$, minerals, and water permeate the membrane (called permeate; Pouliot, 2008; Smith, 2013). When a $0.1 \mu \mathrm{m}$ MF membrane is used with skim milk, ca- 
sein micelles are retained, and milk serum protein or whey protein passes through the membrane, effectively creating micellar casein concentrates (MCC) and milkderived whey protein. A simplified schematic of MCC and milk-derived whey protein manufacture is represented in Figure 2. Ultrafiltration predates MF in the dairy industry and is widely used in the manufacture of concentrated milk proteins and milk for cheesemaking (Maubois, 1986). Ultrafiltration membranes have a pore size ranging from 10 to $100 \mathrm{~nm}$, with processing pressures of 0.1 to $1.0 \mathrm{MPa}$ (Pouliot, 2008; Smith, 2013). During UF of skim milk, lactose, minerals, and water partition into the permeate, and proteins and fat partition into the retentate. This partitioning of components yields a protein-rich retentate and a carbohydrate- and mineral-rich permeate. Reverse osmosis is a concentration technique, and thus has a smaller pore size and $(<1 \mathrm{~nm})$ a higher processing pressure (3.0-5.0 MPa; Pouliot, 2008; Smith, 2013). Nanofiltration is a "loose" $\mathrm{RO}$, with a pore size of 1 to $10 \mathrm{~nm}$ and lower processing pressure of 1.5 to 3.0 MPa (Pouliot, 2008; Smith, 2013). It is a fractionation technique and rejects components besides water and monovalent salts.

Membrane technology provides several options for dairy processing. Membrane materials can be polymers (cellulose acetate, polysulphone/polyethersulphone, polyamide, polyvinylidene fluoride, and polypropylene) or inorganic materials (ceramic, metallic; Jensen and Kønigsfeldt, 2000). A more hydrophilic and negatively charged membrane is desired to avoid protein fouling. Besides consideration of material choice, the cost of installation and operation often dictate membrane choice. The capital investment for polymeric membranes is one-tenth that of ceramic membranes, and ceramic membranes have a wider $\mathrm{pH}$ and temperature range and a longer life (at least 10 years, compared to 0.5 years for a polymeric membrane; Park et al., 2014; Gitis and Rothenberg, 2016). Generally in dairy, polyamide is used for RO, polyvinylidene fluoride and polypropylene for MF and UF, and ceramic for MF (Carvalho and Maubois, 2009). Membrane technology also provides several modules to house membranes. Polymer membranes are commonly housed in plate-and-frame, spiral-wound, and hollow-fiber modules, and inorganic membranes have their own tubular-designed module. Selection of membranes is a balance between target products, raw material, processing efficiency, and the costs of installation, operation, and maintenance.

Membrane materials also differ in terms of method and efficiency of separation. Ceramic MF membranes are designed for high cross-flow velocity while maintaining low transmembrane pressure. This keeps the permeate passage consistent down the length of the membrane and prevents major fouling with a high rate

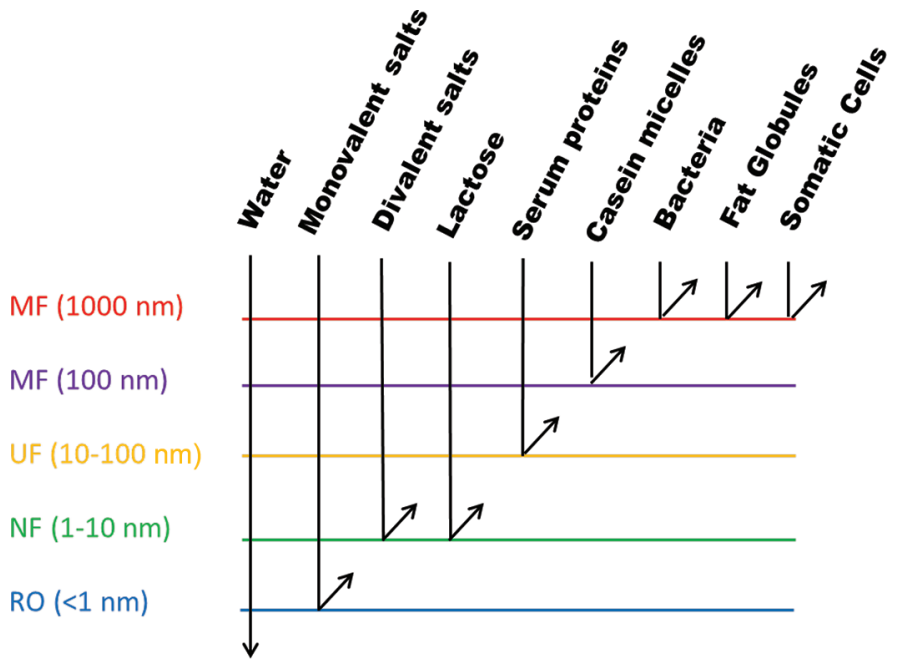

Figure 1. Passed and rejected dairy components based on membrane pore size. $\mathrm{MF}=$ microfiltration, $\mathrm{NF}=$ nanofiltration, $\mathrm{RO}=$ reverse osmosis, $\mathrm{UF}=$ ultrafiltration.

of permeate passage (Karasu et al., 2010). Uniform transmembrane pressure allows maximum passage of permeate and is achieved by using an additional pump to recirculate the permeate, leveling out the transmembrane pressure. Ceramic membranes have a very uniform pore size distribution, which allows the separation of molecules by size. On the other hand, polymeric membranes form a foulant or concentration polarization layer, which in reality dictates the separation rather than the declared molecular weight cutoff. Depending on the system design, polymeric systems may have unfavorable processing conditions of high transmembrane pressure and low cross-flow velocity, leading to lower performance and less efficiency of separation compared with optimized ceramic systems (Karasu et al., 2010).

\section{Microfiltration}

As indicated earlier, 2 sizes of MF are used in dairy processing: $1.4 \mu \mathrm{m}$ for bacterial removal with ceramic membranes, and $0.1 \mu \mathrm{m}$ for the remove of fat and the separation of casein and whey protein. Microfiltration membranes are available in both ceramic and polymeric spiral-wound forms. Because MF membranes have a larger pore size, they can foul more quickly than other types of membranes. Generally, to prevent fouling, a high cross-flow velocity can be applied to create lift of the particles, keeping the pores of the membrane clear. Spiral-wound polymeric membranes cannot handle high cross-flow velocity, because it causes the membranes to telescope (mechanical deformation of the center of the membrane pulling out of the outer wraps). Most systems have anti-telescoping devices to hold the 


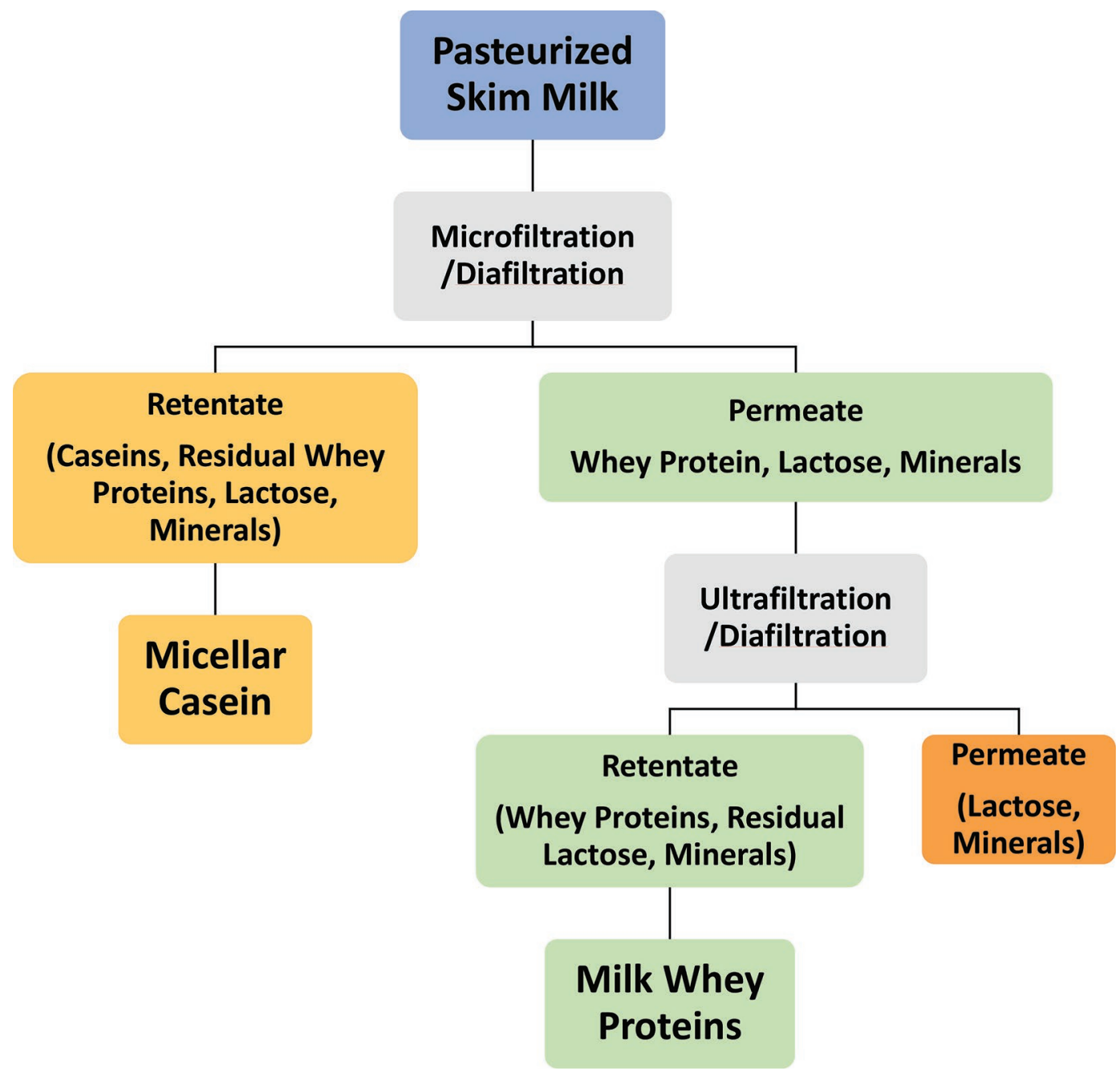

Figure 2. Schematic of micellar casein and milk-derived whey protein manufacture.

membrane shape. To reduce fouling on ceramic MF, a higher cross-flow velocity $(5-7 \mathrm{~m} / \mathrm{s})$ is applied on the retentate side by increasing the retentate recirculation pump rate. This introduces high wall shear stress and washes away the foulant on the membrane surface. Two modified ceramic membranes have been developed to achieve optimal transmembrane pressure and prevent fouling, either by changing the thickness of the supporting material or changing the thickness of the membrane along its length. These modifications are meant to mimic the performance of uniform transmembrane pressure (UTP) membranes. Both of these modified ceramic membranes are more economical options, because they can operate without the need for a permeate recirculation pump, reducing operating costs.

Although MF can be used for many functions, including bacteria removal, fat removal, and milk fat globule membrane separation, this review focuses on the separation of casein and whey proteins from skim milk. Both polymeric and ceramic membranes can be used to achieve this, although, as indicated earlier, they vary greatly in performance and processing efficiency. Early studies on the separation of micellar casein and milk whey protein from skim milk by MF were conducted in the 1990s. The pore size of MF membranes that work for the separation of casein and whey proteins are usually 0.1 or $0.14 \mu \mathrm{m}$ for ceramic MF and 0.1 to $0.5 \mu \mathrm{m}$ for spiral-wound MF. These pore sizes are based on the size of the protein: micellar casein (50-500 $\mathrm{nm}$ ) is rejected by the MF membrane as retentate, and whey protein $(3-6 \mathrm{~nm})$ passes through the membrane as permeate (Saboya and Maubois, 2000; Fox and McSweeney, 2003). However, if the skim milk is pasteurized at high temperatures $\left(>78^{\circ} \mathrm{C}\right)$, whey proteins will denature and form large particles (aggregates), or the denatured whey protein will adhere to the casein mi- 
celle itself, which will not pass through the membrane (Saboya and Maubois, 2000). As a result, the retentate will not be micellar casein but a product more similar to milk protein concentrate in terms of the ratio of casein to whey protein.

A 70 to $80 \%$ whey protein transmission was achieved by $0.1 \mu \mathrm{m}$ ceramic MF applied to skim milk (Le Berre and Daufin, 1996). Samuelsson, et al. (1997) reported that a higher processing temperature and higher crossflow velocity favored whey protein removal from skim milk via MF. An $88 \%$ whey protein removal was obtained from skim milk at $55^{\circ} \mathrm{C}$ with a circulation velocity of $8 \mathrm{~m} / \mathrm{s}$ and $0.14 \mu \mathrm{m}$ ceramic MF (Samuelsson et al., 1997). Several studies have addressed micellar casein and whey protein separation by both ceramic (UTP, graded permeability and Isoflux) and spiral-wound (with polyvinylidene difluoride as membrane material) MF. In a single stage (no diafiltration or dilution) at $3 \times[\times$ (concentration factor) $=$ total volume/retentate volume] MF of skim milk at $50^{\circ} \mathrm{C}$, ceramic UTP MF had the highest whey protein removal (64.40\%), followed by graded permeability $(61.04 \%)$ and spiralwound (38.62\%; Zulewska et al., 2009). The whey protein removal from skim milk was significantly increased in UTP (achieved 95\%) and spiral-wound (achieved $70.3 \%$ ) MF when engaging diafiltration (Beckman et al., 2010). The low whey protein removal rate in spiralwound MF could have been due to fouling caused by the higher hydrophobicity of polymeric membranes and lower cross-flow velocity (Beckman et al., 2010). For spiral-wound MF, 95\% whey protein removal from skim milk was achieved through an 8-stage MF with 7 stages of diafiltration at $50^{\circ} \mathrm{C}$ (Beckman et al., 2010). The membrane choice by the processor - apart from the purity of the casein and whey protein stream needed - is also dictated by the capital and running costs of the membrane.

\section{MICELLAR CASEIN}

No standard of identity exists for MCC in the United States or Europe. However, the American Dairy Product Institute (ADPI) defines a microfiltered milk product as either microfiltered milk protein or micellar casein that has an adjusted ratio of casein to whey proteins (ADPI, 2018a). Other milk protein ingredients, such as milk protein isolate and milk protein concentrate, retain the same natural ratio of casein to whey protein found in milk (80:20; ADPI, 2018a). Compositionally, the protein content as a percentage of the total solids determines whether the powder or liquid is a concentrate or an isolate. Micellar casein products that have been generated or researched to date are concentrates (approximately $85 \%$ protein), and thus MCC is the most commonly referenced name. An MCC will have a different ratio of casein to whey protein, with a higher proportion of casein than an milk protein concentrate. As an ingredient, $\mathrm{MCC}$ evolved with the development of cost-effective MF membranes that had improved separation efficiencies.

In the United States, MCC is used primarily as a high-quality protein source to fortify food applications. Although the Food and Drug Administration (FDA) exercises enforcement discretion in the use of UF milk to manufacture standardized cheese, the use of microfiltered milk (and thus MCC) is not permitted. In the European Union, microfiltered milk is commonly used for the standardization of cheese milk, improving cheese yields (Neocleous et al., 2002; Culhane, 2016). The use of microfiltered milk has several potential benefits for cheese manufacture. First, cheese yield is increased by raising the percentage of casein per unit volume (Neocleous et al., 2002). Cheeses made from nonfortified milk typically generate 1 part cheese and 9 parts whey. Fortifying the casein content of cheese milk increases the cheese yield per hundredweight of milk used. Govindasamy-Lucey et al. (2007) made pizza cheese with cold polymeric microfiltered milk and found increased cheese yields without compromising the quality or functional attributes of the cheese. Second, whey protein ingredients from the permeate stream of microfiltered skim milk have no cheese-ingredient residuals or glycomacropeptide that may enable the use of these protein ingredients in specific food applications. A more detailed explanation of the differences in whey protein produced by MF of skim milk versus cheesemaking will be covered in later sections. Third, the use of microfiltered milk allows for more accurate casein standardization of cheese milk. Currently, the fat and protein content of cheese milk are adjusted to a specific ratio depending on the desired composition of the final cheese using skim milk subjected to evaporation, nanofiltration, or RO. All of these methods require additional process modifications that make them less desirable when compared with standardization using microfiltered milk. However, protein standardization may not be the most accurate technique, because total protein includes whey proteins, which are lost during the manufacture of most cheese varieties. Cheese milk standardization with MF involves fat separation of the incoming milk into skim milk and cream, followed by MF of the skim milk into a casein-rich retentate stream. Cream is added to the retentate to standardize fat for final cheese manufacture (Brandsma and Rizvi, 2001).

Microfiltration used to increase the solids or casein content of cheese milk has shown promise as a novel alternative to traditional cheesemaking process (Nelson and Barbano, 2005), but procedures need to be adjust- 
ed to overcome changes to gelation kinetics (Brandsma and Rizvi, 2001; Amelia and Barbano, 2013; Lu et al., 2016). Protein and fat retention is improved by 4 to $5 \%$ (Garem et al., 2000), and starter and rennet quantity can be reduced. Lu et al. (2017) investigated cheesemaking with cheese milk enriched with MCC to a casein content of 3.2 to $10.9 \%$. They concluded that cheesemaking with MF- and UF-enriched milk needed to address cheesemaking procedures because of changes related to the following: effects on downstream processing because of less whey generation; changes to ionic strength and buffering of the milk, which could influence gelation kinetics; and potential changes to rennet and culture usage rate. Casein-enriched cheese milk can be pasteurized at higher time-temperature combinations $\left(110-140^{\circ} \mathrm{C}, 10 \mathrm{~s}\right)$ than conventionally pasteurized milk, with minimal effects on gelation kinetics. Decreased micellar interactions of $\kappa$-casein and $\beta$-lactoglobulin is hypothesized to minimize the effect of heat treatment on cheesemaking (Dalgleish, 1990). Papadatos et al. (2003) conducted an economic feasibility analysis of the MF of skim milk before cheesemaking, including the cost and production of coproducts. Based on data from 1998 to 2000, they found that net revenue was higher in 30 of the 36 mo examined. The net revenue compared with conventional cheesemaking was increased by $\$ 0.41$ for Cheddar and $\$ 0.45$ for mozzarella per $100 \mathrm{lb}$. (approximately $45 \mathrm{~kg}$ ) of standardized milk, strengthening the economic argument of allowing microfiltered milk in cheesemaking.

\section{IMPORTANCE OF CASEIN PURITY FOR DEFINING AND NAMING MCC}

The ADPI provides a standard way to define the total protein of an $\mathrm{MCC}$ powder, but this naming mechanism does not provide information about casein purity. Because the purity of the MCC is one of the key intrinsic factors that affects its flavor and functionality (discussed later in the paper), it should be an important criterion in the naming of the MCC. Therefore, one of the important calls to action for the dairy industry is to devise a way to name MCC ingredients based on their purity. Traditionally, the nomenclature of dairy protein concentrates produced from whey and milk lists the type of protein using a short 3-letter code followed by a number that distinguishes the percent protein of the dry matter. For instance, WPC 34 is a whey protein concentrate (WPC) with $34 \%$ protein on a dry-matter basis. However, the naming of MCC is different because in addition to total protein content, it needs to communicate its purity using either the amount of casein as a percentage of the true protein present in the MCC, or the amount of milk-derived whey protein that has been removed from the original milk in addition to the percentage of protein. Without an appropriate standard or label, MCC cannot be economically or functionally differentiated from milk protein isolate or milk protein concentrate.

Correctly measuring the purity of MCC after spraydrying would likely require HPLC or SDS-PAGE analysis to measure the amount of whey protein. Kjeldahl analysis of liquid MCC before spray-drying would allow the measurement of residual whey protein, but after heat treatment, Kjeldahl analysis would be an inaccurate technique for measuring residual whey proteins in MCC because of partial whey protein denaturation and binding to casein (Verdi et al., 1987). Additional research is needed to compare methods of assessing MCC purity before and after spray-drying, because MCC purity may affect both flavor and functionality in ingredient applications. Table 1 summarizes the nutrition composition of protein ingredients from milk.

\section{FUNCTIONAL PROPERTIES OF MCC}

Caseins exist as colloidal complexes and compose $80 \%$ of the proteins in bovine milk (Schmidt, 1980). Classical separation techniques of casein from milk involve isoelectric precipitation and enzymatic hydrolysis of the proteins (by the action of rennet). Microfiltration is a physical separation process that can isolate

Table 1. Typical composition of dairy protein concentrates ${ }^{1}$

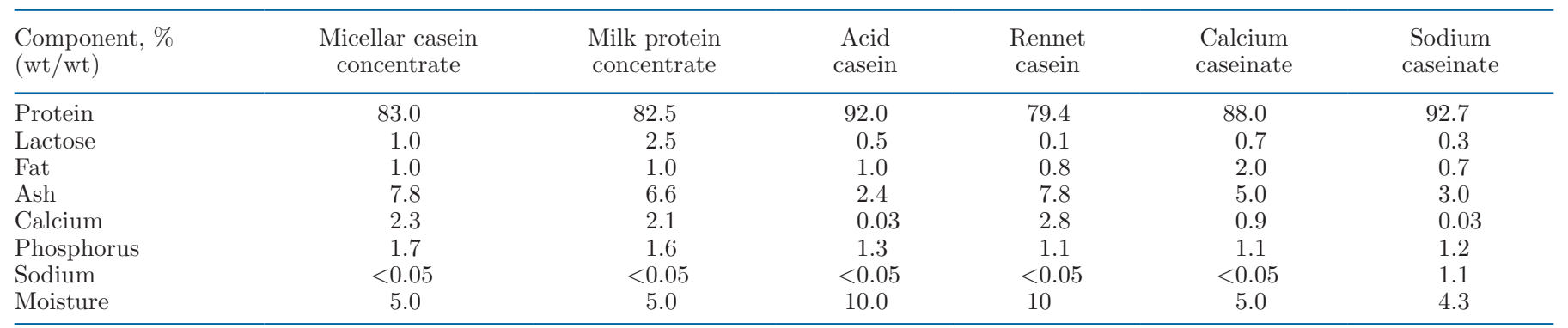

\footnotetext{
${ }^{1}$ Adapted from the Dairy Export Council (2015).
} 
caseins in their native form, providing protein ingredients with a unique set of functionalities compared to other methods of isolating casein (Lu et. al., 2015). At the same time, a significant opportunity exists to improve the functional properties of MCC, such as its heat stability and hydration, because these properties are the cornerstone of any high-protein ingredient in food applications.

\section{Heat Stability}

New product launches of food and beverages with "added protein" or "high/source of protein" saw a compound annual growth rate of $20.7 \%$ from 2014 to 2018, and MCC is an ingredient that can capitalize on this protein trend. Beverages on the shelf are primarily UHT-processed and have a shelf life of greater than 6 mo at room temperature. Sauer and Moraru (2012) investigated the application of MCC in beverages processed though UHT and retort, and their results emphasized a limitation with powdered MCC: it is difficult to disperse into solutions, and when exposed to the high temperatures of UHT treatment and retort sterilization, aggregation and coagulation are observed. Beliciu et al. (2012) achieved similar results, but they concluded that retort processing had less of an effect on the casein micelles and produced a more homogeneous beverage with both liquid and powdered MCC. Studies have shown that decreasing the temperature or increasing the $\mathrm{pH}$ prevents the aggregation and coagulation of MCC during processing (Sauer and Moraru, 2012).

The heat stability of liquid MCC (5-10\% protein wt/ wt) was poor at UHT and retort temperatures (Beliciu et al., 2012). Probable causes attributed to its poor heat stability could be the following: casein instability at high temperatures due to calcium phosphate precipitation; or heat-induced dissociation of $\kappa$-casein, leading to casein instability. Liquid MCC (5-10\% protein wt/ wt) had a greater heat stability than rehydrated MCC powder under UHT processing $\left(142^{\circ} \mathrm{C}, 3 \mathrm{~s}\right.$; Beliciu et al., 2012; Lu et al., 2015). Stabilizers often used in protein beverages may offer solutions for improving heat stability.

\section{Solubility}

Solubility during the rehydration of MCC powders has also been a limiting factor in its use in foods and beverages (Burgain et al., 2016; Zhang et al., 2018). Proteins need to be rehydrated to ensure maximum functionality and heat stability (Crowley et al., 2015). The main theory explaining the poor rehydration properties of MCC powder is that the casein micelles are slow to release into solution from the powder particles
(Schokker et al., 2011). Mimouni et al. (2009) proposed that this mechanism of casein micelle dissolution should be considered the rate-limiting step of MCC solubility, rather than wetting of the actual powder. The MCC powder, with a protein content of approximately $80 \%$ on a dry-matter basis, had lower solubility than "low heat" milk powder (Schuck et al., 1994a). Time (30-40 min), temperature $\left(35-60^{\circ} \mathrm{C}\right)$, and high shear are effective in ensuring proper hydration of MCC powders (Schuck et al., 1994b; Fang et al., 2010; Mimouni et al., 2010). Increasing the ionic strength of water for dispersion and adding a calcium chelator $(60 \mathrm{~m} M$ trisodium citrate) enhanced the dispersion and solubility of highly concentrated MCC powder in water (Lu et al., 2015).

Higher storage temperature and longer time negatively affected the rehydration of MCC powders (Gaiani et al., 2007). The storage conditions of the powder need to be considered as a crucial step in minimizing the loss of solubility of MCC powders over time (Burgain et al., 2016; Nasser et al., 2017a). Multiple phenomena occur during the storage of MCC powder that are directly correlated with its ability to rehydrate. Burgain et al. (2016) was the first to discover that the surface of the individual MCC powder particles became rougher and hardened during storage, forming a skin-like surface layer. This formation of a skin layer at the surface is what is thought to inhibit the release of casein micelles into solution. Storage time and temperature were key components in affecting the severity of the surface hardening. Powders stored at a constant temperature of $20^{\circ} \mathrm{C}$ or lower showed little change in rehydration rate and maintained a minimum of $80 \%$ solubility compared with a control for up to 12 mo (Nasser et al., 2017b). This is probably a similar mechanism to the poor solubility of milk protein concentrate powder, especially with prolonged and elevated storage (Smith et al., 2016). However, the benefit of milk protein concentrate is that a portion of its protein sources come from highly soluble whey proteins.

Another phenomenon observed over the shelf life of MCC powder is change in the secondary structure of the proteins, with an observable loss of $\alpha$-helix structure and potential increase in $\beta$-sheet formation. The loss of $\alpha$-helix structure is directly correlated with loss of solubility (Nasser et al., 2018). These changes are thought to be due to protein-protein interactions and cross linkage, causing increased aggregation. The protein aggregation is driven by hydrophobic interactions, resulting in an increase in powder particle size that has a direct and detrimental effect on the solubility (Havea, 2006; Schokker et al., 2011).

Despite these factors that contribute to the poor rehydration of MCC powder, steps can be taken to improve the solubility of MCC powder. The main 
treatments currently involve treatment with calcium chelating salts (citrates, phosphates) and increasing ionic strength (addition of $\mathrm{NaCl}$ ) before spray-drying (Schuck et al., 2002; Schokker et al., 2011). The addition of UF permeate from skim milk MF permeate (primarily lactose and minerals) and $\mathrm{NaCl}$ to $\mathrm{MCC}$ (liquid) before spray-drying significantly improved MCC rehydration (Schuck et al., 2002; Gaiani et al., 2005). This could have been because of the hygroscopic nature of lactose and the lowering of $\mathrm{Ca}^{2+}$ ion activity due to changes in the ionic strength of the medium (Schuck et al., 2002). Poor rehydration properties have also been noted with other high-casein powders, such as milk protein concentrate (Sikand et al., 2011; Smith et al., 2016). Non-agglomerated MCC powder showed faster rehydration than agglomerated MCC powder, the opposite of the finding for whey protein isolate powders (Gaiani et al., 2007). A recent study by Zhang et al. (2018) showed promising potential in the use of high-intensity ultrasound to decrease the rehydration time of MCC.

\section{Cold Gelation}

Because of the difficulties that MCC powder presents in the rehydration process, liquid highly concentrated MCC (HC-MCC) has been developed. This product has a protein content of $\geq 18 \%$ (wt/wt; Amelia and Barbano, 2013a; Lu et al., 2016). Although it avoids the challenge of rehydration, it presents a unique challenge of its own, in the form of a strong gel at lower temperatures $\left(\sim 20^{\circ} \mathrm{C}\right.$; Amelia and Barbano, 2013; Lu et al., 2016). It is important to note that HC-MCC is pourable and pumpable at room temperature $\left(22^{\circ} \mathrm{C}\right.$; Amelia and Barbano, 2013). However, the gel formed by the cooling of HC-MCC can only be broken up by heating to approximately $50^{\circ} \mathrm{C}(\mathrm{Lu}$ et al., 2016). The properties and mechanisms of this cold gelation phenomenon require further study, but $\mathrm{Lu}$ et al. (2016) have done preliminary work in this area. Lu et al. (2015) proposed that HC-MCC cold gelation was caused by casein micelles being so close together; because of the high concentration, steric hindrance from the protein tendrils increased, preventing movement of particles in the solution and causing a gel structure. When not enough energy (heat) is available to overcome this repulsion, the gel becomes especially strong. However, this theory has not been directly tested or confirmed, and will require further research to verify.

Still, HC-MCC can be used for cheesemaking. It is combined with cream and skim milk to create a recombined concentrated milk (RCM) that has high casein and low whey protein, making it ideal for cheesemaking. Lu et al. (2016) also investigated whether RCM would retain the gelation properties of HC-MCC, even with decreased protein content $(\approx 12 \%)$ and at casein-to-fat ratios of $0.8,1.0$, and 1.2 . They found that $12 \% \mathrm{RCM}$ still had cold gelation $\left(\leq 12^{\circ} \mathrm{C}\right)$, and the temperature at which the gel formed depended on a variety of factors, such as protein level, $\mathrm{pH}$, and calcium and salt additions. Interestingly, cold gelation has the opposite thermal properties of rennet coagulated milk: an increase in temperature causes an increase in the gel strength of rennet gel, but it causes a decrease in the gel strength of HC-MCC and RCM. This is thought to be because at high temperatures in $\mathrm{HC}-\mathrm{MCC}$, the casein micelles stay more tightly bound as a result of increased hydrophobic interactions. At lower temperatures, the protein strands are less tightly bound to the micelle and can extend further outward, allowing for intermolecular interactions. This process is different for rennet-treated milk, which has an increased speed of aggregation with an increase in temperature, because the micelles have had $\kappa$-casein cleaved and are driven together through entropic and hydrophobic interactions (Lu et al., 2016). The mechanism for gelation as proposed by $\mathrm{Lu}$ et al. (2015) becomes less apparent when using RCM because the casein micelles are spaced further apart and should experience less steric hindrance. It is hypothesized that the increase in free protein strands might result in entanglements, which could restrict the movement of particles (Lu et al., 2016).

Protein content, $\mathrm{pH}$, and the addition of calcium and citrate salts are known to influence the temperature at which gelation occurs. The cold gelation temperature of RCM is directly correlated with $\mathrm{pH}$ from 6.4 to 7.0. For every 0.1-unit reduction in $\mathrm{pH}$, the temperature of cold gelation decreased by approximately $7^{\circ} \mathrm{C}$, and this affect was consistent across all protein levels (8-12\%). A probable reason for the increase in temperature for cold gelation with an increase in $\mathrm{pH}$ is casein dissociation from the micelle and lower steric hindrance (Lu et al., 2016). The addition of calcium can have differing effects, depending on the levels of calcium added. If added at $0.12 \mathrm{mmol} / \mathrm{g}$ casein or lower, then it has no significant effect, but if added at $0.17 \mathrm{mmol} / \mathrm{g}$ casein or higer, then the temperature for cold gelation increases. The addition of citrate also showed a significant and linear relationship with the temperature for cold gelation: for every $0.1 \mathrm{mmol} / \mathrm{g}$ casein increase of added citrate, the average cold gelation temperature increased about $6^{\circ} \mathrm{C}$. As mentioned previously, citrate addition is linked to the dissociation of the casein micelle, which would result in the release of more free protein strands into solution, which could lead to the entanglement of protein strands that can restrict movement. Study in this area is relatively new, and more research is needed to substantiate these hypotheses. 


\section{Sensory Properties}

Flavor studies on MCC are limited. Rehydrated MCC powder was characterized by sweet aromatic, cooked or milky, and cardboard or doughy flavors, and had a distinct corn chip flavor compared with liquid MCC (Smith et al., 2016; Carter et al., 2018). Liquid milk protein concentrate and MCC were similar in flavor, but in freshly made powders that were rehydrated, MCC had a tortilla flavor and the milk protein concentrate did not (Carter et al., 2018). Tortilla flavor has been noted in rehydrated milk protein concentrate and rehydrated milk protein isolate after storage (Smith et al., 2016). Several flavor compounds have been identified in milk protein concentrate that correspond with tortilla flavor, which may result from Maillard browning, lipid oxidation, or amino acid degradation (Smith et al., 2016). As the protein concentration of milk protein concentrates increase from skim milk powder to milk protein isolate, the sweet aromatic flavor decreases and the cardboard flavor increases, presumably due to aromatic flavor compounds passing through the UF membranes during the stages of diafiltration required to achieve high levels of protein purity (Drake et al., 2009; Park et al., 2016; Smith et al., 2016). Amelia et al. (2013) manufactured a low-fat Cheddar cheese (6\% fat) using a novel method from rehydrated spray-dried MCC powder (95\% reduced serum protein) and shredded, partially defatted Cheddar cheese. The resulting low-fat Cheddar cheese had undesirable off-flavors (tortilla flavor, bitter taste), and some typical aged Cheddar flavors were missing. Some of these sensory properties might be attributed to the spray-dried MCC powder used, but the process used to generate the cheese was also not typical cheesemaking from fluid milk.

Consumers expect great flavor in fluid milk and protein beverages (Oltman et al., 2015; Harwood and Drake, 2018). Cooked and sulfur flavors are disliked by consumers (Lee et al., 2017). Research has suggested that high heat processes such as ultrapasteurization lead to sulfur and eggy flavors in milk and protein beverages. These off-flavors have been sourced to whey proteins (Jo et al., 2019). Therefore, depending on the purity (i.e., lack of milk whey protein) of the MCC prepared from skim milk in a high heat process, the sulfur and eggy flavors may be decreased. This potential flavor change following ultrapasteurization or retort processing might be a marketable point of difference for high-purity MCC compared with milk protein isolate.

\section{APPLICATIONS IN MILK-BASED BEVERAGES}

Micellar casein concentrate has many qualities that make it ideal for food application: ability to bind large amounts of calcium associated with casein; lower in lactose; bland in flavor; mouthfeel that is similar to fat; and white color (Barbano, 2009; Amelia and Barbano, 2013; Carter et al., 2018). The literature cites various applications of MCC: shelf-stable beverages, Greekstyle yogurt, cheese, and nutrition bars.

Vogel (2019) manufactured vanilla-flavored milk protein beverages ( 15 and 25 g protein per $240 \mathrm{~mL}$ serving) from liquid MCC (95\% whey protein reduced), liquid milk protein concentrate, and liquid blends of milk protein concentrate and serum protein isolate (also called milk whey protein isolate). Beverages were ultrapasteurized by direct steam injection and evaluated over 8 wk of refrigerated storage. Sulfur and eggy flavors were documented in the beverages made with milk protein concentrate and with milk protein concentrate and serum protein isolate, but not in the beverages made with MCC. Sulfur and eggy flavors are drivers of dislike for consumers (Lee et al., 2017). Vanilla flavor was also higher in the beverages made with MCC beverages than in those made with milk protein concentrate or milk protein concentrate and serum protein isolate, by both sensory and instrumental measurement. The reduction of sulfur and eggy flavors and the higher vanilla flavor represent potential advantages for the application of MCC in the expanding beverage market. However, the specific concentration or concentration range of whey protein that causes detectable (unpleasant) sulfur and eggy flavors is unknown, and the purity necessary for MCC to manufacture protein beverages free of offflavors is currently unknown.

When increasing the protein concentration of a beverage, MF offers the opportunity to selectively produce a beverage that is high in milk-derived whey protein or in milk casein. The influence of these 2 groups of proteins on beverage color, viscosity, and cooked sulfur or eggy flavor are different. In general, protein beverages with higher casein content are lighter in color, show a temperature-dependent viscosity profile, and have less sulfur or eggy flavor than a milk-based beverage with higher milk-derived milk whey protein when ultrapasteurized (Lee et al., 2017; Cheng et al., 2019a,b; Jo et al., 2019). At 4 and $25^{\circ} \mathrm{C}$, the viscosity of milkbased beverages changed with increasing fat levels and increasing levels of casein as a percentage of protein (Rudan and Barbano, 1999). The viscosity of protein beverages largely depends on the amount of protein, but can be influenced by protein type. Achieving the correct viscosity, texture, and mouthfeel requires an understanding of individual protein types.

Color also influences consumer preferences for fluid milks and milk beverages (Quiñones et al., 1997, 1998). McCarthy et al. (2017) reported that better color or whiteness was an important reason that drinkers of skim 
milk, $2 \%$ fat milk, and whole milk all preferred milks with a higher fat level. As such, appearance is a critical parameter for preference of fluid milk. Phillips et al. (1995) found that increasing the milk fat level (0.06 to $2.0 \%$ ) increased the L-value (whiteness) and decreased the a-value (greenness to redness) and b-value (blueness to yellowness), which were well correlated with the perceived color of low-fat milk by sensory analysis with trained panels. More recently, Cheng et al. (2018) documented that temperature had a large effect on the perceived color (appearance) of skim milk and fat-free milk beverages, but not on milks or beverages containing fat. Increasing the true protein level (Quiñones et al., 1997, 1998) and casein as a percentage of true protein (Misawa et al., 2016) increased the whiteness of low-fat milks and caused sensory perception of these low-fat milks to be more similar to higher-fat milks. Rudan and Barbano (1999) also reported that increasing casein as a percentage of true protein increased the whiteness of milk-based beverages. Milk whiteness increased with increasing casein as a percent of true protein, causing lower-fat beverages to have similar whiteness to higherfat beverages. Increased whiteness is a positive attribute that consumers value in fluid milk. This means that a milk beverage that has the same protein content as milk but that has all its protein from casein (MCC) will be whiter. For this reason, MCC has been used as the base ingredient for coffee creamers (Merrill and Jiancai, 2017).

Bong and Moraru (2014) reported that MCC powders could be used to fortify the protein content of Greekstyle yogurt and eliminate the acid whey removal in conventional processing. In this study, MCC 58 (freezedried) and MCC 88 (spray-dried) were used: the numbers signify the total nitrogen protein (both MCCs had $85-88 \%$ casein as a percentage of true protein). The acidification rate of the Greek-style yogurt was faster than the traditional control, but MCC 58 was a better alternative to conventional processing than MCC 88 (Bong and Moraru, 2014). Powdered MCC was combined with skim milk to increase the yogurt base protein content, and the MCC 58 powder dispersed easily in the milk with no visible aggregation or coagulation. However, the authors also reported differences in physicochemical properties between the MCC-fortified and regular Greek-style yogurts (Bong and Moraru, 2014). Sensory properties were not addressed.

Salunke (2013) produced processed-cheese products and mozzarella cheese analogs with MCC that were treated with or without transglutaminase, finding that MCC can effectively replace rennet casein in those applications. Moreover, mineral-reduced MCC has shown the ability to produce processed-cheese products with reduced levels of emulsifying salts, enhancing the pos- sibility of cheeses with a clean-label process (Metzger, 2018).

Another food application for MCC is nutrition bars. Simple protein bars were manufactured with a mixture of protein ingredients, high-fructose corn syrup, and glycerol to compare different dairy protein powders and hardening behavior over shelf life (Hogan et al., 2012). After $10 \mathrm{~d}$ of storage at $37^{\circ} \mathrm{C}$, the MCC-based nutrition bars were softer in texture than bars made with whey protein hydrolysates, whey protein isolate, or sodium caseinate (Hogan et al., 2012). Banach et al. (2016) found that high-protein nutrition bars made with milk protein concentrate were harder and more cohesive than bars made with MCC. More research needs to be conducted to better understand the unique functionality MCC with respect to the physicochemical properties of protein bars.

\section{MILK-DERIVED WHEY PROTEIN}

To this point, we have reviewed MCC, which is the retentate stream obtained during MF of skim milk. The major component of the permeate stream of the same MF process is serum proteins or whey proteins. Traditionally, the liquid substance obtained by separating the coagulum from milk, cream, or skim milk in cheesemaking has been called whey (FDA, 2019), and proteins isolated from them are called whey protein. The Generally Recognized As Safe notification from the FDA also specifies the origin of whey (from cheese manufacture), and this has led to a debate in the industry around the nomenclature of whey proteins obtained from the MF of fluid skim milk. Tradition and previous scientific literature have called this protein stream serum proteins, and serum protein concentrates and isolates. However, this wording may be confusing to consumers, and the industry needs a way to differentiate whey proteins separated directly from milk by filtration from those isolated from cheese or rennet or acid casein manufacture. To help with this, the ADPI has created an industry standard for this protein stream called "milk whey proteins" (ADPI, 2018b). Although many terms are used in the literature, we will refer to milk whey protein concentrate ( $\mathbf{m W P C}$ ) and milk whey protein isolate (mWPI) as having 34 to $89 \%$ and $90 \%$ protein, respectively.

The milk whey protein market is growing. No data are available on production numbers to distinguish them from traditional cheese whey products. Milk whey protein is similar to traditional whey protein and fits into many of the same product applications, but some key factors differentiate milk whey proteins from traditional cheese whey protein. Because milk whey protein is not derived from cheese manufacture, it is free of 
the residues of cheesemaking, including starter culture residues, dead or living cells, thermoduric bacteria or bacteriophages, enzyme, colorants, or bleaching agents (Kang et al., 2010; Campbell and Drake, 2013). This makes milk whey protein particularly useful in applications such as infant formula, where regulations limit the ingredients that can be present in whey as a result of carryover from previous processes. It also means that a higher premium can be demanded for milk whey protein.

\section{Composition, Industry Standards, and Labeling}

Although WPC and mWPC are similar in composition, they differ in fat content, and $\mathrm{mWPC}$ has no glycomacropeptide (no rennet is used). Because mWPC contains no glycomacropeptide, the yield of whey protein per unit volume is lower than whey protein isolated from cheesemaking: glycomacropeptide is retained by $\mathrm{UF}$ and composes a large proportion of whey protein powder (approximately 20\%) from traditional membrane fractionation (Farías et al., 2010). The percentage of casein in WPC and mWPC also vary; WPC has lower amounts of casein, because rennet is more selective than a membrane (Evans et al., 2010).

Evans et al. (2009, 2010) compared WPC and mWPC (34 and 80\%) made from cheese manufacture or by ceramic MF of skim milk. The WPC made from cheese manufacture had a higher fat content. This was due to the UF step that retains the fat; the MF step of $\mathrm{mWPC}$ completely removes the fat, because it is retained with the casein. Fat content on a dry weight basis of WPC80 ranges between 6 and $8 \%$, and mWPC 80 had a fat content of $0.5 \%$ (Evans et al., 2009). The fat content was more similar to whey protein isolate, which typically has 0.5 to $1.0 \%$ lipids. Reconstituted WPC and $\mathrm{mWPC} 34 \%$ at $10 \%$ solids also had a different appearance. The mWPC was clear and the WPC was cloudy, presumably due to the fat content. One of the other key differences is $\mathrm{pH}$. The $\mathrm{pH}$ of cheese WPC is lower because of the lactic acid produced by the starter culture. Given the slight difference $\mathrm{pH}$, it is possible that the mineral content differed (WPC $80 \mathrm{pH} 6.51$, mWPC $80 \mathrm{pH}$ 6.87; Evans et al., 2010). As well, WPC 34 and 80 had a higher calcium content than mWPC (Evans et al., 2009; Evans et al., 2010).

The composition of mWPC can change based on the membrane used and the temperature of filtration. Coppola et al. (2014) compared mWPC processed at different temperatures with polymeric membranes, and the residual casein as a percentage of true protein in the mWPC changed with the temperature. The residual casein percentage in the mWPC varied from $1.0 \%$ to over $20 \%$ depending on the temperature of $\mathrm{MF}$, with higher temperatures retaining more casein (Coppola et al., 2014). Even $1 \%$ of casein had a dramatic effect on the clarity of the milk whey protein stream. Milk whey protein with $1 \%$ casein had a light transmission rate of $94 \%$, compared to traditional WPC, which had a light transmission rate of $15 \%$ (Coppola et al., 2014), meaning that even with a small amount of casein contamination, mWPC is less turbid than traditional WPC because of the higher fat content of WPC.

It has been proposed that the casein that passes through the MF membrane at cold temperatures is $\beta$-casein (Coppola et al., 2014). At $4^{\circ} \mathrm{C}, \beta$-caseins exist in solution as monomers of molecular mass $25 \mathrm{kDa}$ (Fox and McSweeney, 1998) and disassociate from the casein micelle (Davies and Law, 1983; Famelart et al., 1989) with decreasing temperature, from 50 to $4^{\circ} \mathrm{C}$. The use of cold MF has been successfully adapted to fractionate caseins from skim milk by Terre et al. (1987) and van Hekken and Holsinger (2000). Filtration conducted at higher temperatures retains more casein and makes a purer milk whey protein stream. Allowing $\beta$-casein transmission during MF may be beneficial for making unique casein fractions and a unique permeate stream that may be useful for infant formula, but appearance and composition limit milk whey protein with high casein in typical whey protein applications. Whey protein products with high amounts of casein scatter more light, cause turbidity at a given percentage, and have decreased solubility at low $\mathrm{pH}$.

The amount of $\beta$-casein transmission also seems to be a function of the membrane type used. Zulewska et al. (2018) found that regardless of different heat treatments $(1.4 \mu \mathrm{m}$ MF filtration, thermization, and pasteurization at $72^{\circ} \mathrm{C}$ for $15 \mathrm{~s}$ ) the ceramic MF membrane used in the study $(0.1 \mu \mathrm{m})$ yielded less than $1 \%$ $\beta$-casein at $6^{\circ} \mathrm{C}$ in the permeate. Cold $\mathrm{MF}$ at $7^{\circ} \mathrm{C}$ done by Coppola et al. (2014) with a spiral-wound polymeric membrane $(0.08 \mu \mathrm{m})$ resulted in $22 \%$ casein in the protein fraction of the milk whey ingredient. This study did not identify the casein type or discuss membrane performance (leakage) at the processing temperatures used.

\section{Functional Properties}

Several studies have addressed the physical and functional properties of milk whey protein. For example, mWPC has good clarity, heat gelation, solubility, and foaming properties (Heino et al., 2007; Luck et al., 2013). As well, mWPC and mWPI obtained from MF had lower fat, less heat treatment because cheese whey is usually pasteurized 2 times, less protein denaturation, and no glycomacropeptide compared to WPC or whey protein isolate (Heino et al., 2007; Evans et al., 
2009, 2010; Coppola et al., 2014; Qiu et al., 2015). However, $\mathrm{mWPI}$ processed from MF at a lower temperature $\left(7^{\circ} \mathrm{C}\right)$ contained a high amount of $\beta$-casein, and mWPI processed from $50^{\circ} \mathrm{C} \mathrm{MF}$ had no $\beta$-casein (Coppola et al., 2014).

The color of liquid mWPI (10.88\% protein content, wt/wt) was reported as amber to reddish as a result of the high concentration of lactoferrin and lactoperoxidase (Misawa et al., 2016). The instrumental color of mWPC34 powder and WPC34 powder were identical (Evans et al., 2009). Rehydrated mWPC34 and mWPC80 powders, both with a fat content of $0.02 \%$, were clear, and rehydrated WPC34 and WPC80 were opaque because of the higher fat content (Evans et al., 2009, 2010).

The solubility of mWPC34 and mWPC80 powders was the same as WPC powder, and rehydrated mWPC34 and mWPC80 powders were less turbid than rehydrated WPC34 and WPC80 powders $(\mathrm{pH}$ 3-7) (Bacher and Kønigsfeldt, 2000; Heino et al., 2007; Luck et al., 2013). As well, mWPC34 and mWPC80 showed better gelation and foaming than WPC because of lower glycomacropeptide and fat content and less heat-induced protein denaturation (Mangino et al., 1987; Morr and Ha, 1993; Heino et al., 2007; Luck et al., 2013). A milk whey protein solution (skim milk MF permeate concentrated and dialyzed to $5 \%$ protein content) showed an overrun volume identical to that of egg white protein (5\% protein content) at $\mathrm{pH} 7$ (Punidadas and Rizvi, 1998). Coppola et al. (2014) reported that $\mathrm{mWPI}$ processed at $7^{\circ} \mathrm{C} \mathrm{MF}$ with a high amount of $\beta$-casein produced a more stable foam than mWPI processed from $50^{\circ} \mathrm{C} \mathrm{MF}$. The unfolding of $\beta$-casein would expose more hydrophilic groups (Swaisgood, 2003). The unfolding and annealing of $\beta$-casein on the interface of air and water could decrease surface tension and stabilize the foam. Drying methods (spray-drying and freeze-drying) had no effect on the turbidity, gelation, or foaming of mWPC34 and mWPC80 (Luck et al., 2013).

\section{Sensory Properties}

Rehydrated spray-dried mWPC34 powder had no buttery (diacetyl) or cardboard flavors compared to WPC34 powder (spray-dried and freeze-dried), presumably because of lower fat content, processing time, and lipid oxidation compounds (Evans et al., 2009). The WPC34 had a low intensity of cardboard flavor, but the mWPC had none. Cardboard flavor has been documented in whey protein products and is associated with secondary lipid oxidation products (Mahajan et al., 2004; Carunchia Whetstine et al., 2005; Evans et al., 2009, 2010; Whitson et al., 2010, 2011; Carter and Drake, 2018). Whey protein isolated from colored cheese manufacturing requires bleaching to remove the residual colorant that leaches into the whey stream, but bleaching of whey has negative effects on the whey protein flavor (McDonough et al., 1968; Croissant et al., 2009; Kang et al., 2010; Listiyani et al., 2011; Kang et al., 2012; Listiyani et al., 2012; Jervis et al., 2012, 2015; Li et al., 2012; Campbell et al., 2013; Fox et al., 2013). Bleaching chemicals had a similar effect on milkderived whey protein (Jervis et al., 2012). Increased cardboard or fatty and cabbage flavors and higher lipid oxidation compounds are present from the chemical and enzymatic bleaching of fluid whey (Campbell et al., 2013). In a study of acidic protein beverages formulated with commercial WPC80 powders, and pilot plant spray-dried mWPC80 (Evans et al., 2010), the beverages made with mWPC80 had equal or higher liking scores for aroma, appearance, and mouthfeel compared to the beverages made with WPC80. In contrast, the mWPC80 beverages had lower flavor and overall liking scores than the beverages made with 3 of the 4 commercial WPC80 powders (Evans et al., 2010). The authors attributed these differences to higher intensities of soapy flavor and bitter taste in the mWPC 80 beverages compared to the WPC80 beverages. Soapy flavor is a documented sensory attribute in acidified and heated whey protein isolate solutions that has also been documented in rehydrated WPI at neutral $\mathrm{pH}$ (White et al., 2013; Oltman et al., 2015). The flavor has been described by trained panelists as similar to that of medium-chain free fatty acids, but an exact source of this off-flavor has not been confirmed.

\section{Food Applications}

The applications of milk-derived whey protein are similar to those of cheese-derived whey protein, and include ready-to-mix and ready-to-drink beverages, snacks, bars, yogurt, sour cream, baked goods, and infant formula. The high level of protein purity and the absence of cheesemaking byproducts make milk-derived whey protein an ideal protein source for any of these applications. Its high clarity at low and high $\mathrm{pH}$ levels also makes it a versatile ingredient for ready-to-mix and ready-to-drink protein beverages.

\section{FUTURE NEEDS}

From a functional perspective, MCC and milk whey protein have flavor and functional differences from milk protein concentrate or isolate and from whey protein concentrate or isolate. A wide array of dairy ingredients can offer the industry formulation tools to meet product claims, provide clean-label solutions, 
and offer desired sensory properties. Additional studies with ingredient applications can establish the unique contributions of each dairy protein ingredient. Industry standards for the nomenclature of MCC need to be clearly established to permit communication with processors and consumers about what products are being delivered. The use of MCC in cheesemaking could allow the United States industry greater flexibility and offer improved operational efficiencies. More studies need to be done to establish the functional and sensory properties of MCC, mWPC and mWPI compared to emerging alternative proteins to highlight the uniqueness of these ingredients in food applications.

\section{CONCLUSION AND SUMMARY}

Advancements in filtration technology have allowed for the advancement of dairy ingredient production and technology. The primary protein fractions in milk (casein and serum or milk-derived whey protein) can be directly and effectively separated by filtration, creating 2 highly nutritious and distinct functional protein streams: micellar casein and milk-derived whey protein. Micellar casein composition and functionality can vary depending on purity, and methods of production and labeling guidelines need to account for these differences. Milk-derived whey protein is a highly valuable coproduct of the MF of milk, with sensory and functional properties similar to but distinct from traditional whey proteins. As more protein ingredients emerge to compete, it is important to demonstrate the strengths of dairy ingredients in the protein market. These ingredients allow the dairy industry in the United States and around the world more flexibility to create unique products for an ever-changing consumer base.

\section{ACKNOWLEDGMENTS}

Funding was provided in part by the National Dairy Council (Rosemont, IL). The authors have not stated any conflicts of interest.

\section{REFERENCES}

ADPI. 2018a. Concentrated milk proteins standard. Accessed Mar. 2, 2020. www.adpi.org/Portals/0/Standards/ ConcentratedMilkPowder_book.pdf.

ADPI. 2018b. Milk whey protein standard. Accessed Mar. 2, 2020. https://www.adpi.org/Portals/0/Standards/Milk\%20Whey\%20 Protein.pdf.

Amelia, I., and D. M. Barbano. 2013. Production of an 18\% protein liquid micellar casein concentrate with a long refrigerated shelf life. J. Dairy Sci. 96:3340-3349. https://doi.org/10.3168/jds.2012 $-6033$.

Amelia, I., M. A. Drake, B. Nelson, and D. M. Barbano. 2013. A new method for the production of low-fat Cheddar cheese. J. Dairy Sci. 96:4870-4884. https://doi.org/10.3168/jds.2012-6542.
Bacher, T.,, and P. Kønigsfeldt. 2000. WPI by microfiltration of skim milk. Eur. Dairy Mag. 12:14-16.

Banach, J. C., S. Clark, L. E. Metzger, and B. P. Lamsal. 2016. Textural performance of crosslinked or reduced-calcium milk protein ingredients in model high-protein nutrition bars. J. Dairy Sci. 99:6061-6070. https://doi.org/10.3168/jds.2016-10995.

Barbano, D. M. 2009. Milk protein products - what are they and what role do they play in lactose reduced (low "carb") foods? Accessed Aug. 9, 2018. www.comefarmwithus.com/wp-content/uploads/ 2013/02/Milk-Protein-Product-Fact-Sheet-3-10-09.pdf.

Beckman, S. L., J. Zulewska, M. Newbold, and D. M. Barbano. 2010. Production efficiency of micellar casein concentrate using polymeric spiral-wound microfiltration membranes. J. Dairy Sci 93:4506-4517.

Beliciu, C. M., A. Sauer, and C. I. Moraru. 2012. The effect of commercial sterilization regimens on micellar casein concentrates. J. Dairy Sci. 95:5510-5526. https://doi.org/10.3168/jds.2011-4875.

Bong, D. D., and C. I. Moraru. 2014. Use of micellar casein concentrate for Greek-style yogurt manufacturing: Effects on processing and product properties. J. Dairy Sci. 97:1259-1269. https://doi .org $/ 10.3168 /$ jds.2013-7488.

Brandsma, R. L., and S. S. H. Rizvi. 2001. Manufacture of Mozzarella cheese from highly-concentrated skim milk microfiltration retentate depleted of whey proteins. Int. J. Food Sci. Technol. 36:611624. https://doi.org/10.1046/j.1365-2621.2001.00507.x.

Burgain, J., J. Scher, J. Petit, G. Francius, and C. Gaiani. 2016. Links between particle surface hardening and rehydration impairment during micellar casein powder storage. Food Hydrocoll. 61:277285. https://doi.org/10.1016/j.foodhyd.2016.05.021.

Campbell, R. E., S. Adams, M. A. Drake, and D. M. Barbano. 2013. Effect of bleaching permeate from microfiltered skim milk on $80 \%$ serum protein concentrate. J. Dairy Sci. 96:1387-1400. https://doi .org/10.3168/jds.2012-6053.

Campbell, R. E., and M. A. Drake. 2013. Invited review: The effect of native and nonnative enzymes on the flavor of dried dairy ingredients J. Dairy Sci. 96:5435-5454. https://doi.org/10.3168/jds .2013-6598.

Carter, B. G., and M. A. Drake. 2018. Invited review: The effects of processing parameter on the flavor of whey protein ingredients. J. Dairy Sci. 101:6691-6702. https://doi.org/10.3168/jds.2018-14571.

Carter, B., H. Patel, D. M. Barbano, and M. A. Drake. 2018. The effect of spray drying on the difference in flavor and functional properties of liquid and dried whey proteins, milk proteins, and micellar casein concentrates. J. Dairy Sci. 101:3900-3909. https:// doi.org/10.3168/jds.2017-13780.

Carunchia Whetstine, M. E., A. E. Croissant, and M. A. Drake. 2005. Characterization of dried whey protein concentrate and isolate flavor. J. Dairy Sci. 88:3826-3839. https://doi.org/10.3168/jds.S0022 -0302(05)73068-X.

Carvalho, A. F., and J. L. Maubois. 2009. Applications of membrane technologies in the dairy industry. Pages 33-56 in Engineering Aspects of Milk and Dairy Products. J. S. R. Coimbra and J. A. Teixeria, ed. CRC Press, Boca Raton, FL.

Cheng, N., D. M. Barbano, and M. A. Drake. 2018. Hunter versus CIE color measurement systems for analysis of milk-based beverages. J. Dairy Sci. 101:4891-4905.

Cheng, N., D. M. Barbano, and M. A. Drake. 2019a. Effect of pasteurization and fat, protein, casein to serum protein ratio, and milk temperature on milk beverage color and viscosity. J. Dairy Sci 102:2022-2043. https://doi.org/10.3168/jds.2018-15739.

Cheng, N., D. M. Barbano, and M. A. Drake. 2019b. Effects of milk fat, casein, and serum protein concentrations on sensory properties of milk based beverages. J. Dairy Sci. 102:8670-8690. https://doi .org/10.3168/jds.2018-16179.

Coppola, L. E., M. S. Molitor, S. A. Rankin, and J. A. Lucey. 2014. Comparison of milk derived whey protein concentrates containing various levels of casein. Int. J. Dairy Technol. 67:467-473. https:/ /doi.org/10.1111/1471-0307.12157.

Croissant, A. E., E. J. Kang, R. E. Campbell, E. Bastian, and M. A. Drake. 2009. The effect of bleaching agent on the flavor of liquid 
whey and whey protein concentrate. J. Dairy Sci. 92:5917-5927. https://doi.org/10.3168/jds.2009-2535.

Crowley, S. V., B. Desautel, I. Gazi, A. L. Kelly, T. Huppertz, and J. A. O'Mahony. 2015. Rehydration characteristics of milk protein concentrate powders. J. Food Eng. 149:105-113. https://doi.org/ 10.1016/j.jfoodeng.2014.09.033.

Culhane, M. 2016. Filtered Milk for Cheese and Ingredient Production. US Dairy Export Council, Arlington, VA.

Dairy Export Council. 2015. Micellar casein concentrate. Accessed Jan. 1, 2020. www.thinkusadairy.org/resources-and-insights/resources -and-insights/product-resources/micellar-casein-concentrate.

Dalgleish, D. G. 1990. The effect of denaturation of $\beta$-lactoglobulin on renneting - a quantitative study. Milchwissenschaft 45:491-494.

Davies, D. T., and A. J. R. Law. 1983. Variation in the protein composition of bovine casein micelles and serum casein in relation to micellar size and milk temperature. J. Dairy Res. 50:67-75. https: //doi.org/10.1017/S0022029900032532.

Drake, M. A., R. E. Miracle, and J. M. Wright. 2009. Sensory properties of dairy proteins. Pages $429-448$ in Milk Proteins: From Expression to Food. A. Thompson, M. Boland, and H. Singh, ed. Elsevier, Amsterdam, the Netherlands.

Evans, J., J. Zulewska, M. Newbold, M. A. Drake, and D. M. Barbano. 2009. Comparison of composition, sensory, and volatile components of thirty-four percent whey protein and milk serum protein concentrates. J. Dairy Sci. 92:4773-4791. https://doi.org/10.3168/ jds.2009-2194.

Evans, J., J. Zulewska, M. A. Newbold, M. A. Drake, and D. M. Barbano. 2010. Comparison of composition and sensory properties of $80 \%$ whey protein and milk serum protein concentrates. J. Dairy Sci. 93:1824-1843. https://doi.org/10.3168/jds.2009-2723.

Famelart, M. H., C. Hardy, and G. Brulé. 1989. Etude des facteurs d'extraction de la caséine $\beta$. Lait 69:47-57. https://doi.org/10 .1051/lait:198914. [In French; English abstract]

Fang, Y., C. Selomulya, and X. D. Chen. 2010. Characterization of milk protein concentrate solubility using focused beam reflectance measurement. Dairy Sci. Technol. 90:253-270. https://doi.org/10 $.1051 /$ dst/2009050.

Farías, M., M. Martinez, and A. Pilosof. 2010. Casein glycomacropeptide pH-dependent self-assembly and cold gelation. Int. Dairy J. 20:79-88. https://doi.org/10.1016/j.idairyj.2009.09.002.

Fox, A. J., T. J. Smith, P. D. Gerard, and M. A. Drake. 2013. The influence of bleaching agent and temperature on bleaching efficacy and volatile components of fluid whey and whey retentate. J. Food Sci. 78:C1535-C1542. https://doi.org/10.1111/1750-3841.12251.

Fox, P. F., and P. L. H. McSweeney. 1998. Milk proteins. Pages 180 181 in Dairy Chemistry and Biochemistry. 1st ed. P. F. Fox and P. L. H. McSweeney, ed. Thomas Science, London, United Kingdom.

Fox, P. F., and P. L. H. McSweeney. 2003. Advanced Dairy Chemistry. Dairy Chemistry and Biochemistry. 2nd rev. ed. Kluwer Academic/Plenum Publishers, New York.

Gaiani, C., S. Banon, J. Scher, P. Schuck, and J. Hardy. 2005. Use of a turbidity sensor to characterize micellar casein powder rehydration: Influence of some technological effects. J. Dairy Sci. 88:27002706. https://doi.org/10.3168/jds.S0022-0302(05)72948-9.

Gaiani, C., P. Schuck, J. Scher, S. Desobry, and S. Banon. 2007. Dairy powder rehydration: Influence of protein state, incorporation mode, and agglomeration. J. Dairy Sci. 90:570-581. https://doi .org/10.3168/jds.S0022-0302(07)71540-0

Garem, A., P. Schuck, and J. L. Maubois. 2000. Cheesemaking properties of a new dairy-based powder made by a combination of microfiltration and ultrafiltration. Lait 80:25-32. https://doi.org/ 10.1051/lait:2000104.

Gitis, V., and G. Rothenberg. 2016. Ceramic Membranes: New Opportunities and Practical Applications. Wiley-VCH, Weinheim, Germany.

Govindasamy-Lucey, S., J. J. Jaeggi, M. E. Johnson, T. Wang, and J. A. Lucey. 2007. Use of cold microfiltration retentates produced with polymeric membranes for standardization of milk for manufacture of pizza cheese. J. Dairy Sci. 90:4552-4568. https://doi .org/10.3168/jds.2007-0128.
Harwood, W. S., and M. A. Drake. 2018. Identification and characterization of fluid milk consumer groups. J. Dairy Sci. 101:8860-8874. https://doi.org/10.3168/jds.2018-14855.

Haug, A., A. T. Hostmark, and O. M. Harstad. 2007. Bovine milk in human nutrition-A review. Lipids Health Dis. 6:25-40. https:// doi.org/10.1186/1476-511X-6-25.

Havea, P. 2006. Protein interactions in milk protein concentrate powders. Int. Dairy J. 16:415-422. https://doi.org/10.1016/j.idairyj .2005.06.005.

Heino, A. T., J. O. Uusi-rauva, P. R. Rantamäki, and O. Tossavainen. 2007. Functional properties of native and cheese whey protein concentrate powders. Int. J. Dairy Technol. 60:277-285. https://doi .org/10.1111/j.1471-0307.2007.00350.x.

Hoffman, J. R., and M. J. Falvo. 2004. Protein-Which is best? J. Sports Sci. Med. 3:118-130.

Hogan, S. A., V. Chaurin, B. T. O'Kennedy, and P. M. Kelly. 2012. Influence of dairy proteins on textural changes in high-protein bars. Int. Dairy J. 26:58-65. https://doi.org/10.1016/j.idairyj.2012.02 .006 .

Jensen, J. A., and P. Kønigsfeldt. 2000. Membranes. Chapter 4 in Membrane Filtration and Related Molecular Separation Technologies. APV Systems, Denmark.

Jervis, M. G., T. J. Smith, and M. A. Drake. 2015. The influence of solids concentration and bleaching agent on bleaching efficacy and flavor of sweet whey powder. J. Dairy Sci. 98:2294-2302. https:// doi.org/10.3168/jds.2014-8804.

Jervis, S., R. Campbell, K. L. Wojciechowski, E. A. Foegeding, M. A. Drake, and D. M. Barbano. 2012. Effect of bleaching whey on sensory and functional properties of $80 \%$ whey protein concentrate. J. Dairy Sci. 95:2848-2862. https://doi.org/10.3168/jds.2011-4967.

Jo, Y., B. G. Carter, D. M. Barbano, and M. A. Drake. 2019. Identification of the source of volatile sulfur compounds produced in milk during thermal processing. J. Dairy Sci. 102:8658-8669. https:// doi.org/10.3168/jds.2019-16607.

Kang, E. J., R. E. Campbell, E. Bastian, and M. A. Drake. 2010. Invited review: Annatto usage and bleaching in dairy foods. J. Dairy Sci. 93:3891-3901. https://doi.org/10.3168/jds.2010-3190.

Kang, E. J., T. J. Smith, and M. A. Drake. 2012. Alternative bleaching methods for Cheddar cheese whey. J. Food Sci. 77:C818-C823. https://doi.org/10.1111/j.1750-3841.2012.02774.x.

Karasu, K., N. Glennon, N. D. Lawrence, G. W. Stevens, A. J. O'Connor, A. R. Barber, S. Yoshikawa, and S. E. Kentish. 2010. A comparison between ceramic and polymeric membrane systems for casein concentrate manufacture. Int. J. Dairy Technol. 63:284-289. https://doi.org/10.1111/j.1471-0307.2010.00582.x.

Le Berre, O., and G. Daufin. 1996. Skim milk crossflow microfiltration performance versus permeation flux to wall shear stress ratio. J. Membr. Sci. 117:261-270. https://doi.org/10.1016/0376 $-7388(96) 00076-2$.

Lee, A. P., D. M. Barbano, and M. A. Drake. 2017. The influence of ultra-pasteurization by indirect heating versus direct steam injection on skim and $2 \%$ fat milk. J. Dairy Sci. 100:1688-1701. https: //doi.org/10.3168/jds.2016-11899.

Li, X. E., R. E. Campbell, A. J. Fox, P. D. Gerard, and M. A. Drake. 2012. Influence of storage, heat treatment, and solids composition on the bleaching of whey with hydrogen peroxide. J. Food Sci. 77:C798-C804. https://doi.org/10.1111/j.1750-3841.2012.02749.x.

Listiyani, M. A. D., R. E. Campbell, R. E. Miracle, D. M. Barbano, P. D. Gerard, and M. A. Drake. 2012. Effect of temperature and bleaching agent on bleaching of liquid cheddar whey. J. Dairy Sci. 95:36-49. https://doi.org/10.3168/jds.2011-4557.

Listiyani, M. A. D., R. E. Campbell, R. E. Miracle, L. O. Dean, and M. A. Drake. 2011. Influence of bleaching on flavor of $34 \%$ whey protein concentrate and residual benzoic acid concentration in dried whey proteins. J. Dairy Sci. 94:4347-4359. https://doi.org/ 10.3168/jds.2011-4341.

Loeb, S., and S. Sourirajan. 1963. Sea water demineralization by means of an osmotic membrane. Adv. Chem. Ser. 38:117-132. https://doi .org/10.1021/ba-1963-0038.ch009. 
Lu, Y., D. J. McMahon, L. E. Metzger, A. Kommineni, and A. H. Vollmer. 2015. Solubilization of rehydrated frozen highly concentrated micellar casein for use in liquid food applications. J. Dairy Sci. 98:5917-5930. https://doi.org/10.3168/jds.2015-9482.

Lu, Y., D. J. McMahon, and A. H. Vollmer. 2016. Investigating cold gelation properties of recombined highly concentrated micellar casein concentrate and cream for use in cheese making. J. Dairy Sci. 99:5132-5143. https://doi.org/10.3168/jds.2015-10791.

Lu, Y., D. J. McMahon, and A. H. Vollmer. 2017. Investigating rennet coagulation properties of recombined highly concentrated micellar casein concentrate and cream for use in cheese making. J. Dairy Sci. 100:892-900. https://doi.org/10.3168/jds.2016-11648.

Luck, P. J., B. Vardhanabhuti, Y. H. Yong, T. Laundon, D. M. Barbano, and E. A. Foegeding. 2013. Comparison of functional properties of $34 \%$ and $80 \%$ whey protein and milk serum protein concentrates. J. Dairy Sci. 96:5522-5531. https://doi.org/10.3168/jds .2013-6617.

Mahajan, S. S., L. Goddik, and M. C. Qian. 2004. Aroma compounds in sweet whey powder. J. Dairy Sci. 87:4057-4063. https://doi .org/10.3168/jds.S0022-0302(04)73547-X.

Mangino, M. E., Y. Y. Liao, N. J. Harper, C. V. Morr, and J. G. Zadow. 1987. Effects of heat processing on the functionality of whey protein concentrates. J. Food Sci. 52:1522-1524. https://doi .org/10.1111/j.1365-2621.1987.tb05869.x.

McCarthy, K. S., K. Lopetcharat, and M. A. Drake. 2017. Milk fat threshold determination and the effect of milk fat content on consumer preference for fluid milk. J. Dairy Sci. 100:1702-1711. https: //doi.org/10.3168/jds.2016-11417.

McDonough, F. E., R. E. Hargrove, and R. P. Tittsler. 1968. Decolorization of annatto in Cheddar cheese whey. J. Dairy Sci. 51:471472. https://doi.org/10.3168/jds.S0022-0302(68)87011-0.

Merrill, R. K., and L. Jiancai. 2017. Micellar casein for coffee creamers and other dairy products. Leprino Foods Company, assignee. US Pat. No. WO2017003708A1.

Metzger, L. E. 2018. Method and system for manufacturing mineral reduced micellar casein concentrate. US Patent Application No. US 20180343880A1. Accessed Apr. 28, 2020. https://patents.google .com/patent/US20180343880A1/en.

Mimouni, A., H. C. Deeth, A. K. Whittaker, M. J. Gidley, and B. R. Bhandari. 2009. Rehydration process of milk protein concentrate powder monitored by static light scattering. Food Hydrocoll. 23:1958-1965. https://doi.org/10.1016/j.foodhyd.2009.01.010.

Mimouni, A., H. C. Deeth, A. K. Whittaker, M. J. Gidley, and B. R. Bhandari. 2010. Investigation of the microstructure of milk protein concentrate powders during rehydration: Alterations during storage. J. Dairy Sci. 93:463-472. https://doi.org/10.3168/jds.2009 -2369 .

Misawa, N., D. M. Barbano, and M. A. Drake. 2016. Influence of casein as a percentage of true protein and protein level on color and texture of milks containing 1 and $2 \%$ fat. J. Dairy Sci. 99:52845304. https://doi.org/10.3168/jds.2016-10846.

Morr, C. V., and E. Y. W. Ha. 1993. Whey protein concentrates and isolates: processing and functional properties. Crit. Rev. Food Sci. Nutr. 33:431-476. https://doi.org/10.1080/10408399309527643.

Nasser, S., A. Hédoux, A. Giuliani, C. Le Floch-Fouéré, V. SantéLhoutellier, I. de Waele, and G. Delaplace. 2018. Investigation of secondary structure evolution of micellar casein powder upon aging by FTIR and SRCD: Consequences on solubility. J. Sci. Food Agric. 98:2243-2250. https://doi.org/10.1002/jsfa.8711.

Nasser, S., R. Jeantet, P. De-Sa-Peixoto, G. Ronse, N. Nuns, F. Pourpoint, J. Burgain, C. Gaiani, A. Hédoux, and G. Delaplace. 2017b. Microstructure evolution of micellar casein powder upon ageing: Consequences on rehydration dynamics. J. Food Eng. 206:57-66. https://doi.org/10.1016/j.jfoodeng.2017.03.004.

Nasser, S., A. Moreau, R. Jeantet, A. Hédoux, and G. Delaplace. 2017a. Influence of storage conditions on the functional properties of micellar casein powder. Food Bioprod. Process. 106:181-192. https://doi.org/10.1016/j.fbp.2017.09.004.

Nelson, B. K., and D. M. Barbano. 2005. A microfiltration process to maximize removal of serum proteins from skim milk before cheese making. J. Dairy Sci. 88:1891-1900. https://doi.org/10.3168/jds .S0022-0302(05)72865-4.

Neocleous, M., D. M. Barbano, and M. A. Rudan. 2002. Impact of low concentration factor microfiltration on milk component recovery and cheddar cheese yield. J. Dairy Sci. 85:2415-2424. https://doi .org/10.3168/jds.S0022-0302(02)74324-5.

Oltman, A. E., K. Lopetcharat, E. Bastian, and M. A. Drake. 2015. Identifying key attributes for protein beverages. J. Food Sci 80:S1383-S1390. https://doi.org/10.1111/1750-3841.12877.

Papadatos, A., M. Neocleous, A. M. Berger, and D. M. Barbano. 2003. Economic feasibility evaluation of microfiltration of milk prior to cheesemaking. J. Dairy Sci. 86:1564-1577. https://doi.org/10 .3168/jds.S0022-0302(03)73742-4.

Park, C. W., M. A. Stout, and M. A. Drake. 2016. The effect of spraydrying parameters on the flavor of nonfat dry milk and milk protein concentrate 70\%. J. Dairy Sci. 99:9598-9610. https://doi.org/ 10.3168/jds.2016-11692.

Park, S. H., Y. G. Park, J. Lim, and S. Kim. 2014. Evaluation of ceramic membrane applications for water treatment plants with a life cycle cost analysis. Desalin. Water Treat. 54:545-559.

Phillips, L. G., M. L. McGiff, D. M. Barbano, and H. T. Lawless. 1995. The influence of fat on the sensory properties, viscosity and color of low-fat milks. J. Dairy Sci. 78:1258-1266. https://doi.org/10 .3168/jds.S0022-0302(95)76746-7.

Pouliot, Y. 2008. Membrane processes in dairy technology-From a simple idea to worldwide panacea. Int. Dairy J. 18:735-740. https: //doi.org/10.1016/j.idairyj.2008.03.005.

Punidadas, P., and S. S. H. Rizvi. 1998. Separation of milk proteins into fractions rich in casein or whey proteins by cross flow filtration. Food Res. Int. 31:265-272. https://doi.org/10.1016/S0963 -9969(98)00088-X.

Qiu, Y., T. J. Smith, E. A. Foegeding, and M. A. Drake. 2015. The effect of microfiltration on color, flavor, and functionality of $80 \%$ whey protein concentrate. J. Dairy Sci. 98:5862-5873. https://doi .org/10.3168/jds.2014-9174.

Quiñones, H. J., D. M. Barbano, and L. G. Phillips. 1997. Influence of protein standardization by ultrafiltration on the viscosity, color, and sensory properties of skim and 1\% milk. J. Dairy Sci. 80:31423151. https://doi.org/10.3168/jds.S0022-0302(97)76285-4.

Quiñones, H. J., D. M. Barbano, and L. G. Phillips. 1998. Influence of protein standardization by ultrafiltration on the viscosity, color, and sensory properties of 2 and 3.3\% milks. J. Dairy Sci. 81:884894. https://doi.org/10.3168/jds.S0022-0302(98)75647-4.

Rudan, M. A., and D. M. Barbano. 1999. Influence of casein as a percentage of true protein $(\mathrm{CN} \% \mathrm{TP})$ on the properties of milk. J. Dairy Sci. 82(Suppl. 1):4. (Abstr.)

Rutherfurd, S. M., A. C. Fanning, B. J. Miller, and P. J. Moughan. 2015. Protein digestibility-corrected amino acid scores and digestible indispensable amino acid scores differentially describe protein quality in growing male rats. J. Nutr. 145:372-379. https://doi .org/10.3945/jn.114.195438

Saboya, L. V., and J.-L. Maubois. 2000. Current developments of microfiltration technology in the dairy industry. Lait 80:541-553. https://doi.org/10.1051/lait:2000144.

Salunke, P. 2013. Impact of transglutaminase on the functionality of milk protein concentrate and micellar casein concentrate. PhD Thesis. Department of Dairy Science, South Dakota State University, Brookings.

Samuelsson, G., P. Dejmek, G. Trägårdh, and M. Paulsson. 1997. Minimizing whey protein retention in cross-flow microfiltration of skim milk. Int. Dairy J. 7:237-242. https://doi.org/10.1016/S0958 -6946(97)00009-5.

Sauer, A., and C. I. Moraru. 2012. Heat stability of micellar casein concentrates as affected by temperature and $\mathrm{pH}$. J. Dairy Sci. 95:6339-6350. https://doi.org/10.3168/jds.2012-5706.

Schmidt, D. G. 1980. Colloidal aspects of casein. Neth. Milk Dairy J. 34:42-45.

Schokker, E., J. Church, J. Mata, E. Gilbert, A. Puvanenthiran, and P. Udabage. 2011. Reconstitution properties of micellar casein pow- 
der: Effects of composition and storage. Int. Dairy J. 21:877-886. https://doi.org/10.1016/j.idairyj.2011.05.004.

Schuck, P., A. Davenel, F. Mariette, V. Briard, S. Mejean, and M. Piot. 2002. Rehydration of casein powders: Effects of added mineral salts and salt addition methods on water transfer. Int. Dairy J. 12:51-57. https://doi.org/10.1016/S0958-6946(01)00090-5.

Schuck, P., M. Piot, S. Méjean, J. Fauquant, C. Brulé, and J. L. Maubois. 1994b. Déshydratation des laits enrichis en caséine micellaire par microfiltration; comparaison des propriétés des poudres obtenues avec celles d'une poudre de lait ultra-propre. Lait 74:47-63. https://doi.org/10.1051/lait:199415.

Schuck, P., M. Piot, S. Méjean, Y. Le Graet, J. Fauquant, G. Brulé, and J. L. Maubois. 1994a. Déshydratation par atomisation de phosphocaséinate natif obtenu par microfiltration sur membrane. Lait 74:375-388. https://doi.org/10.1051/lait:1994531. [Inhttps:// doi.org/ French; English abstract]

Sikand, V., P. S. Tong, S. Roy, L. E. Rodriguez-Saona, and B. A. Murray. 2011. Solubility of commercial milk protein concentrates and milk protein isolates. J. Dairy Sci. 94:6194-6202. https://doi.org/ 10.3168/jds.2011-4477.

Smith, K. 2013. Development of membrane processes. Pages 1-9 in Membrane Processing: Dairy and Beverage Application. A. Y. Tamime, ed. Blackwell Publishing Ltd., Oxford, UK.

Smith, T. J., R. E. Campbell, Y. Jo, and M. A. Drake. 2016. Flavor and stability of milk proteins. J. Dairy Sci. 99:4325-4346. https:// doi.org/10.3168/jds.2016-10847.

Swaisgood, H. E. 2003. Chemistry of the caseins. Page 164 in Advanced Dairy Chemistry. Volume 1: Proteins. 3rd ed. P. F. Fox and P. L. H. McSweeney, ed. Springer, Boston, MA.

Terre, E., J.-L. Maubois, G. Brulé, and A. Pierre, inventors. 1987. Method for producing a material enriched in beta casein, apparatus for implementing such process, and application of the products obtained by this process as foodstuffs, food supplements or additives in food and pharmaceutical industry or in the production of peptides physiological activity. Institut National de la Recherche Agronomique INRA, Sigma-Tau Industrie Farmaceutiche Riunite SpA, current assignee. Patent no. FR2, 592,769.

van Hekken, D. L., and V. H. Holsinger. 2000. Use of cold microfiltration to produce unique $\beta$-casein enriched milk gels. Lait 80:69-76. https://doi.org/10.1051/lait:2000108.
Verdi, R. J., D. M. Barbano, M. E. Dellavalle, and G. F. Senyk. 1987. Variability in true protein, casein, nonprotein nitrogen, and proteolysis in high and low somatic cell count milks. J. Dairy Sci. 70:230-242. https://doi.org/10.3168/jds.S0022-0302(87)80002-4.

Vogel, K. G., III. 2019. Effect of protein amount and milk protein ingredients on sensory properties and physicochemical properties of ready-to-drink protein beverages. Master's thesis. Food Bioprocessing and Nutrition Sciences, North Carolina State University, Raleigh.

White, S. S., K. M. Fox, S. M. Jervis, and M. A. Drake. 2013. Influence of heating and acidification on the flavor of whey protein isolate. J. Dairy Sci. 96:1366-1379. https://doi.org/10.3168/jds.2012-5935.

Whitson, M., R. E. Miracle, E. Bastian, and M. A. Drake. 2011. Effect of liquid retentate storage on flavor of spray-dried whey protein concentrate and isolate. J. Dairy Sci. 94:3747-3760. https://doi .org/10.3168/jds.2010-4045.

Whitson, M. E., R. E. Miracle, and M. A. Drake. 2010. Sensory characterization of chemical components responsible for cardboard flavor in whey protein. J. Sens. Stud. 25:616-636. https://doi.org/10 .1111/j.1745-459X.2010.00289.x.

Zhang, R., X. Pang, J. Lu, L. Liu, S. Zhang, and J. Lv. 2018. Effect of high intensity ultrasound pretreatment on functional and structural properties of micellar casein concentrates. Ultrason. Sonochem. 47:10-16. https://doi.org/10.1016/j.ultsonch.2018.04.011.

Zulewska, J., J. Kowalik, and B. Dec. 2018. Flux and transmission of beta-casein during cold microfiltration of skim milk subjected to different heat treatments. J. Dairy Sci. 101:10831-10843. https:// doi.org/10.3168/jds.2018-14496.

Zulewska, J., M. Newbold, and D. M. Barbano. 2009. Efficiency of serum protein removal from skim milk with ceramic and polymeric membranes at $50^{\circ}$ C. J. Dairy Sci. 92:1361-1377. https://doi.org/ $10.3168 /$ jds.2008-1757.

\section{ORCIDS}

G. H. Meletharayil @ https://orcid.org/0000-0001-9183-1966

M. A. Drake @ https://orcid.org/0000-0002-4744-2493 